PYTHAGORAS: Jurnal Pendidikan Matematika

Volume 11 - Nomor 2, Desember 2016, (207-218)

Available online at: http://journal.uny.ac.id/index.php/pythagoras

\title{
Pengembangan Pembelajaran Penemuan Terbimbing untuk Meningkatkan Berpikir Kritis dan Motivasi Belajar Geometri di SMP
}

\author{
Siti Nuriyatin $^{1} *$, H. Hartono ${ }^{2}$ \\ ${ }^{12}$ Program Studi Pendidikan Matematika, Universitas Negeri Yogyakarta Jalan Colombo No 1, \\ Karangmalang, Yogyakarta 55281 \\ * Korespondensi Penulis. Email: sitinuriyatin@gmail.com
}

\begin{abstract}
Abstrak
Penelitian ini bertujuan untuk menghasilkan perangkat pembelajaran berbasis penemuan terbimbing untuk meningkatkan kemampuan berpikir kritis dan motivasi belajar matematika pada bangun ruang di SMP. Perangkat yang dikembangkan meliputi silabus, 3 RPP, 8 handout, 8 LKS, 1 perangkat tes ketercapain pada bangun ruang sisi datar; serta silabus, 3 RPP, 2 handout, 4 LKS, 1 perangkat tes ketercapaian kompetensi pada bangun ruang sisi lengkung. Penelitian ini adalah penelitian pengembangan (research \& development) dengan menggunakan model pengembangan 4D yaitu define, design, development, dan disseminate. Kevalidan perangkat ditinjau dari penilaian para ahli, kepraktisan ditinjau dari penilaian guru, penilaian peserta didik, dan observasi keterlaksanaan pembelajaran. Keefektifan ditinjau dari tes ketercapaian kompetensi, tes kemampuan berpikir kritis, dan motivasi belajar matematika peserta didik. Hasil penelitian menunjukkan bahwa perangkat pembelajaran yang dikembangkan valid, praktis, dan efektif.
\end{abstract}

Kata Kunci: pengembangan, perangkat pembelajaran, penemuan terbimbing, berpikir kritis, motivasi belajar matematika

\section{Developing of Guided Inquiry-Based Learning to Increase Critical Thinking and Motivation to Learn on Geometry in Junior High School}

\begin{abstract}
This research was aimed to produce learning kit based guided inquiry to increase critical thinking ablity and motivation to learn mathematics on solid figures and describe the quality of the developed product. The learningkit consist of syllabus, 3 lesson plans, 8 handouts, 8 student worksheets, and a competency achievement test on plane solid figure; and syllabus, 3 lesson plans, 2 handouts, 4 student worksheets, and a competency achievement test on curve solid figure. This research was a developmental research study adapted from 4-D development model. It consisted of four phases: define, design, develop, dan disseminate. The result of validation by expert jugdement shows that the learning kit that was developed was of valid category for each learning kit that has been developed. The aspects of practicality was of very practice category as seen from the evaluation by the teachers, evaluation by the students, and implementation of the learning. The aspect of effectiveness could be reached from the competency achievement test results, critical thinking ability test results, and the results of questionnaires of student's motivation to learn mathematics. The result of this research was learning kit that has been developed valid, practical, and effective.
\end{abstract}

Keywords: development, learning kit, guided inquiry, critical thinking, motivation to learn mathematics

How to Cite: Nuriyatin, S., \& Hartono, H. (2016). Pengembangan pembelajaran penemuan terbimbing untuk meningkatkan berpikir kritis dan motivasi belajar geometri di SMP. PYTHAGORAS: Jurnal Pendidikan Matematika, 11(2), 207-218. doi:http://dx.doi.org/10.21831/pg.v11i2.10656

Permalink/DOI: http://dx.doi.org/10.21831/pg.v11i2.10656 


\section{PENDAHULUAN}

Pendidikan mempunyai peranan penting dalam mempersiapkan manusia yang mampu bersaing di era global. Pentingnya pendidikan ini didukung dengan perumusan fungsi pendidikan nasional oleh pemerintah melalui Undang-Undang Nomor 20 Pasal 3 (2003, p.1), bahwa pendidikan nasional berfungsi mengembangkan kemampuan dan membentuk watak serta peradaban bangsa yang bermartabat dalam rangka mencerdaskan kehidupan bangsa, bertujuan untuk mengembangkan potensi peserta didik agar menjadi manusia yang beriman dan bertakwa kepada Tuhan Yang Maha Esa, berakhlak mulia, sehat, berilmu, cakap, kreatif, mandiri, dan menjadi warga negara yang demokratis serta bertanggung jawab. Dalam era yang semakin berkembang ini, salah satu dampak bagi peserta didik yaitu semakin kompleksnya permasalahan yang akan dihadapi. Oleh karena itu, diperlukan suatu keterampilan yang harus dimiliki peserta didik dalam menyelesaikan permasalahan tersebut. Salah satu kemampuan yang harus dimiliki tersebut adalah kemampuan berpikir kritis.

Salah satu kelebihan seorang pemikir kritis ialah mampu untuk mengidentifikasi poin penting dalam suatu permasalahan, fokus dan mampu observasi dengan teliti, toleran terhadap sudut pandang baru, mau mengakui kelebihan sudut pandang orang lain, dan memiliki kemampuan analisis yang dapat digunakan dalam berbagai situasi (Cottrell, 2005, p.4). Namun sampai saat ini pembelajaran matematika belum memberikan hasil yang sesuai dengan harapan, baik proses maupun hasil pembelajarannya, peserta didik masih mengalami kesulitan menyelesaikan tes berpikir kritis; peserta didik belum terlatih menyelesaikan permasalahan yang menuntut kemampuan kreatifitas, berpikir kritis, dan analitis (Anggraeni, dkk, 2013, p.2; Rosnawati, 2011, pp.5-6), selain itu soal berpikir kritis dalam buku teks yang digunakan hanya mendapatkan porsi 0,39\%-11,63\% (Masduki, dkk, 2013, p.427). Sikap pemikir kritis tersebut diakui sangat diperlukan oleh peserta didik selama proses pembelajaran (Permendiknas Nomor 23, 2006, p.343). Oleh karena itu, pemerintah melakukan berbagai upaya dalam meningkatkan kualitas pendidikan. Salah satu upaya perbaikan tersebut yaitu memilih cara, metode, pendekatan, maupun model pembelajaran yang dapat memperbaiki kualitas belajar peserta didik. Pembelajaran yang baik adalah yang dapat memaksimalkan pengembangan pengalaman peserta didik dengan terlibat aktif dalam kegiatan pembelajaran. Bruner (Kuhlthau, et. al., 2007, p.25) menyarankan agar peserta didik hendaknya belajar dengan berpartisispasi secara aktif dan melakukan penemuan untuk memperoleh pengalaman yang mengizinkan mereka untuk menemukan konsep-konsep dan prinsipprinsip itu sendiri. Hal tersebut dapat difasilitasi melalui pembelajaran penemuan terbimbing.

Carin \& Sund (1989, p.97) juga mengatakan bahwa "guided discovery teaching provides opportunities for greater involvement, giving children more chance to gain insights and better develop their self-concepts". Penemuan terbimbing tersebut memberikan kesempatan bagi keterlibatan yang lebih besar, memberikan lebih banyak kesempatan peserta didik untuk mendapatkan wawasan dan lebih mengembangkan konsep diri peserta didik. Menurut Kuhlthau, et. al. (2007, pp.25-28), penemuan terbimbing mempunyai enam prinsip yaitu children learn by building on what they already know; children develop higher-order thinking through guidance at critical points in the learning process; children have different ways and modes of learning; children learn through social interaction with others; children learn through instruction and experience in accord with their cognitive development; children learn through instruction and experience in accord with their cognitive development. Salah satu prinsip dalam penemuan terbimbing yaitu mengembangkan kemampuan berpikir tingkat tinggi peserta didik. Selanjutnya, Moore \& Stanley (2010, p.10) mengatakan "higher-level thinking is known as critical thinking or higher order thinking". Penjelasan tersebut menekankan bahwa berpikir kritis merupakan bagian dari berpikir tingkat tinggi (higher order thinking). Berdasarkan prinsip penemuan terbimbing, pertanyaan yang diajukan dalam pembelajaran dapat menunjang kemampuan berpikir kritis peserta didik.

French (2004, p.2), menyatakan bahwa "geometrical problems can be approached in a variety of ways:it can be an experimental practical subyect where problems are solved by measurement and calculation". Pernyataan tersebut menunjukkan bahwa geometri merupakan kompetensi yang melibatkan peserta didik dalam pembelajaran secara aktif. Tingkat pemahaman peserta didik terhadap kompetensi matematika ini lebih dipengaruhi oleh pengalaman pribadi dalam mengkonstruksi pengetahuannya yang lebih menekankan pada proses. Dengan demiki- 
an untuk membangun konsep-konsep geometri dapat difasilitasi melalui pembelajaran penemuan terbimbing. Hal ini didukung oleh hasil penelitian Imawan (2015) bahwa penerapan pembelajaran penemuan terbimbing pada matakuliah geometri efektif ditinjau dari prestasi belajar, kepercayaan diri, dan keterampilan berpikir kritis. Selain itu, penelitian sebelumnya yang mengembangkan perangkat pembelajaran menggunakan model penemuan terbimbing oleh Yulianto \& Jailani (2014) menghasilkan perangkat pembelajaran yang valid, praktis, dan efektif.

Keterlibatan peserta didik dalam pembelajaran ini dapat meningkatkan motivasi dalam mempelajari matematika. Menurut Elliott (2000, p.332) bahwa belajar dan motivasi merupakan dua hal yang penting dalam pembelajaran. Berdasarkan observasi yang telah dilakukan menunjukkan bahwa keaktifan peserta didik dalam pembelajaran matematika belumlah sepenuhnya terlaksana. Hal ini dikarenakan pembelajaran masih berpusat pada guru (teacher centered). Oleh karena itu, motivasi merupakan suatu bagian penting yang harus ditumbuhkan dalam setiap pembelajaran yang dilakukan.

Di samping itu dalam dunia pendidikan, sebuah pembelajaran dan kompetensi guru merupakan hal yang tidak dapat dipisahkan. Seorang guru dituntut untuk memiliki sejumlah kemampuan dalam mengelola pembelajaran, pengetahuan yang luas dan pemahaman yang mendalam tentang kompetensi yang akan disampaikan, memiliki keragaman model atau strategi pembelajaran. Dalam merancang dan menerapkan berbagai model pembelajaran dengan tepat, guru mendapat tantangan baru yaitu memahami konsep pembelajaran bahwa peranan guru adalah sebagai fasilitator. Oleh karena itu diperlukan perencanaan dalam menyusun perangkat pembelajaran seperti silabus, RPP, LKS, dan instrumen evaluasi yang berkualitas yang mendukung peranan guru dimana pembelajaran berpusat pada peserta didik.

Namun perangkat pembelajaran yang digunakan belumlah menunjukkan adanya orientasi dalam peningkatan keterampilan berpikir tertentu dalam matematika, seperti kemampuan berpikir kritis. Kelengkapan perangkat pembelajaran dan persiapan yang baik sangat diperlukan agar peserta didik semakin termotivasi dalam belajar matematika. Oleh karena itu diperlukan suatu perangkat pembelajaran yang menunjang peningkatan kemampuan berpikir kritis dan motivasi belajar matematika. Pembelajaran yang dilakukan harus memberikan kesempatan bagi peserta didik untuk terlibat secara aktif dalam pembelajaran. Pembelajaran yang dapat memfasilitasi semua tujuan tersebut yaitu pembelajaran penemuan terbimbing.

Menurut Kuhlthau (2010, p.18) "inquiry that is guided by an instructional team to enable students to gain a depth of understanding and a personal perspective through a wide range of sources of information is called Guided Inquiry". Hal ini menegaskan bahwa pembelajaran penemuan dengan pembimbingan untuk memperoleh pengetahuan yang lebih mendalam melalui berbagai sumber informasi disebut penemuan terbimbing (guided inquiry). Pembimbingan yang dilakukan dapat dilakukan melalui tim pembelajaran yaitu guru dan penyedia sumber informasi di perpustakaan (school librarians). Tahapan penemuan terbimbing meliputi mengidentifikasi masalah, mengumpulkan informasi, menggunakan informasi yang diperoleh pada langkah kedua, dan mengevaluasi (Bell, 1981, p.340; Arends \& Kilcher, 2010, p.269; Moore, 2009, pp.183-184; Depdiknas, 2002, p.12)

Kuhlthau, et. al. (2007, p.25) mengatakan bahwa "children develop higher-order thinking through guidance at critical points in the learning process". Salah satu prinsip dalam penemuan terbimbing tersebut yaitu dalam kondisi kritis tertentu peserta didik dapat mengembangkan kemampuan berpikir tingkat tinggi. Dalam teori konstruktivis yang melandasi pembelajaran penemuan terbimbing akan mengarahkan peserta didik membangun pengetahuannya berdasarkan pengetahuan awal yang dimiliki. Pengarahan yang diberikan dapat melalui pertanyaan-pertanyaan yang diajukan dalam pembelajaran, meliputi; apa yang saya ketahui; apa yang ingin saya ketahui; bagaimana saya menemukannya; apa yang telah saya pelajari; bagaimana saya menggunakan apa yang telah saya ketahui; apa yang selanjutnya akan saya lakukan.

Kemampuan berpikir kritis ini penting dalam pelajaran matematika seperti yang diungkapkan oleh Lunenburg (2012, p.2) yang mengatakan bahwa "... in the minds of students thinking critically, mathematical content is transformed into mathematical thinking". Berpikir kritis juga merupakan berpikir tentang apa yang dipercaya atau dilakukan, seperti yang diungkapkan Ennis (2011, p.1) "critical thinking is reasonable reflective thinking focused on deciding what to believe or do". Kemampuan dalam menimbang dan keyakinan dalam 
memutuskan sesuatu inilah yang sangat diperlukan dalam belajar matematika.

Menurut Facione (2011, p.5) bahwa berpikir kritis meliputi interpretation, analysis, evaluation, inference, explanation, selfregulation. Hal tersebut bermakna sama dengan yang disampaikan oleh Lai (2011, p.2) yang mengatakan bahwa "critical thinking includes the component skills of analyzing arguments, making inferences using inductive or deductive reasoning, judging or evaluating, and making decisions or solving problems". Keterampilan dalam menganalisis argumen, membuat kesimpulan, mengevaluasi, dan memecahkan masalah merupakan bagian dari berpikir kritis.

Glaser (Fisher, 2009, p.3) mendefinisikan berpikir kritis sebagai, (1) an attitude of being disposed to consider in a thoughtful way the problems and subjects that come within the range of one's experience; (2) knowledge of the methods of logical enquiry and reasoning; and (3) some skill in applying those methods. Berpikir kritis merupakan suatu sikap untuk berpikir secara mendalam tentang masalah-masalah dalam jangkauan pengalaman seseorang; merupakan suatu pengetahuan tentang metode yang logis dan penalaran. Interferensi merupakan kemampuan dalam memahami dan mengungkapkan makna dari informasi sebuah permasalahan; analisis merupakan proses mengidentifikasi hubungan antara kesimpulan yang diberikan dan kenyataan sebenarnya, serta menganalisis argumen; evaluasi merupakan kemampuan menemukan kesalahan dalam suatu argumen; sedangkan inferensi merupakan kemampuan membuat kesimpulan dari suatu permasalahan. Dalam penelitian ini ditentukan indikator berpikir kritis yang meliputi interpretasi, analisis, evaluasi, dan inferensi.

Menurut Throwbridge \& Bybee (1986, p.183) bahwa kelebihan dalam discovery juga relevan dengan kelebihan dalam pembelajaran inquiry. Salah satu kelebihan dalam pembelajaran discovery menurut Bruner (2006, p.61) yaitu motivasi yang meliputi motivasi instrinsik dan motivasi ekstrinsik. Banyak faktor yang mempengaruhi motivasi peserta didik. Beberapa diantaranya, Gredler (2011, p.479) bahwa motivasi dapat dipengaruhi oleh nilai tugas dan harapan kesuksesan berprestasi. Gredler (2011, p.478) menambahkan bahwa motivasi berkembang melalui kompleks dari faktor lingkungan dengan faktor dari dalam diri anak. Elliott (2000, p.332) menyatakan bahwa motivation is defined as an internal state that arouses us to action pushes us in particular directions, and keeps us engaged in certain activitie. Learning and motivation are equally essential for performance. Learning enables us to acquire new knowledge and skills, and motivation provides the impetus for showing what we have learned. Hal tersebut menjelaskan bahwa motivasi adalah suatu keadaan dari dalam diri yang menggerakkan untuk bertindak serta menjaga agar tetap dalam suatu aktivitas tertentu. Uraian tersebut juga menjelaskan bahwa belajar dan motivasi merupakan dua hal yang penting dalam pembelajaran. Uraian berbagai faktor motivasi di atas sesuai dengan yang disampaikan Uno (2006, p.23) yaitu bahwa indikator dalam motivasi meliputi (a) adanya hasrat dan keinginan berhasil; (b) adanya dorongan dan kebutuhan dalam belajar, (c) adanya harapan dan cita-cita masa depan, (d) adanya penghargaan dalam belajar, (e) adanya kegiatan yang menarik dalam belajar, (f) adanya lingkungan belajar yang kondusif.

Terkait permasalahan yang telah dikemukakan berikut kajian teorinya, maka penelitian bertujuan untuk menghasilkan perangkat pembelajaran matematika berbasis guided inquiry untuk meningkatkan kemampuan berpikir kritis dan motivasi belajar matematika siswa yang valid, praktis, dan efektif.

\section{METODE}

Jenis penelitian ini adalah penelitian pengembangan (research \& development). Penelitian ini menggunakan model pengembangan 4D yang terdiri atas empat tahapan yaitu define, design, development, dan dissseminate (Thiagarajan, Semmel \& Semmel, 1974, p.6). Penelitian ini dilaksanakan di dua Sekolah Menengah Pertama dari bulan April hingga Mei 2014 sebagai subjek uji coba lapangan dan satu Sekolah Menengah Pertama sebagai subjek uji coba terbatas. Subjek pada uji coba terbatas adalah 9 peserta didik. Subjek pada uji coba lapangan pada masing-masing sekolah sebanyak 33 peserta didik dan 35 peserta didik.

Prosedur pengembangan yang dilakukan meliputi tahap define, design, develop, dan disseminate. Define merupakan tahap menentukan dan mendefinisikan syarat-syarat pembelajaran. Pada tahap ini dilakukan analisis awal akhir, analisis peserta didik, analisis kompetensi, analisis tugas, dan spesifikasi tujuan pembelajaran. Berdasarkan analisis yang dilakukan dalam tahap ini diperoleh solusi dari permasalahan yaitu pengembangan perangkat pembelajaran berbasis penemuan terbimbing untuk 
meningkatkan kemampuan berpikir kritis dan motivasi belajar matematika pada bangun ruang di SMP.

Design merupakan tahap perancangan perangkat pembelajaran dan instrumen penelitian. Kegiatan dalam tahap ini yaitu mengkonstruksi tes menggunakan acuan teori, pemilihan media, pemilihan format, dan perancangan awal. Komponen perangkat yang dikembangkan meliputi silabus, 3 RPP, 8 handout, 8 LKS, dan 1 perangkat tes ketercapaian kompetensi yang terdiri atas 20 soal pilihan ganda pada kompetensi bangun ruang sisi datar; serta silabus, 3 RPP, 2 handout, 4 LKS, dan 1 perangkat tes ketercapaian kompetensi yang terdiri atas 20 soal pilihan ganda pada kompetensi bangun ruang sisi lengkung.

Menurut Nieveen (1999, p.126), "in order to make the concept "quality" more transparent, it was related to a typology of curriculum representations, resulting in a framework with three quality criteria: validity, practicality, and effectiveness". Hal tersebut menunjukkan bahwa kualitas dari sebuah produk yang dikembangkan dinilai dengan kriteria/kualitas valid, praktis, dan efektif. Dalam tahap develop ini merupakan tahapan dalam memperoleh perangkat pembelajaran yang mempunyai kualitas valid, praktis, efektif tersebut. Dalam tahap ini dilakukan validasi perangkat, uji coba terbatas, dan uji coba lapangan. Validasi produk dilakukan oleh satu orang ahli dalam memvalidasi lembar penilaian validasi, dan dua orang ahli yang memvalidasi produk. Uji coba terbatas dilakukan untuk menilai keterbacaan handout, LKS, dan tes ketercapaian kompetensi. Uji coba terbatas dilakukan dengan menggunakan panduan lembar keterbacaan oleh peserta didik. Uji coba lapangan dilakukan untuk mengetahui bagaimana kualitas praktis dan efektif dari perangkat.

Disseminate merupakan tahap terakhir pada penelitian ini. Kegiatan dalam tahap ini yaitu mempublikasikan hasil perangkat yang dikembangkan melalui internet dan guru matematika pada sekolah yang diteliti.

\section{Data, Instrumen dan Teknik Pengumpulan Data}

Data dalam penelitian ini meliputi data kuantitatif dan data kualitatif. Data kuantitatif diperoleh dari hasil tes ketercapaian kompetensi, sedangkan data kualitatif diperoleh dari hasil pengisian lembar validasi, angket (angket penilaian guru, angket penilaian peserta didik, angket motivasi belajar matematika), lembar observasi keterlaksanaan pembelajaran, dan tes kemampuan berpikir kritis. Data kualitatif tersebut diklasifikasikan menjadi lima kategori pilihan. Instrumen untuk menentukan kualitas valid terdiri atas lembar validasi silabus, lembar validasi RPP, lembar validasi handout, lembar validasi LKS, lembar validasi tes ketercapaian kompetensi.

Instrumen yang digunakan untuk mengukur kualitas praktis meliputi lembar penilaian perangkat oleh guru, lembar penilaian handout dan LKS oleh peserta didik, dan lembar observasi keterlaksanaan pembelajaran, sedangkan instrumen untuk mengukur kualitas efektif teridiri dari tes ketercapaian kompetensi, tes kemampuan berpikir kritis, dan angket motivasi belajar matematika. Selain itu, tes kemampuan berpikir kritis digunakan untuk mengetahui peningkatan kemampuan berpikir kritis peserta didik sebelum dan sesudah pembelajaran; angket motivasi belajar matematika digunakan untuk mengetahui peningkatan motivasi belajar matematika peserta didik sebelum dan sesudah pembelajaran.

\section{Teknik Analisis Data}

Data kualitatif berupa hasil pengisian lembar validasi, lembar penilaian oleh guru, lembar penilaian kepraktisan oleh peserta didik, lembar observasi keterlaksanaan pembelajaran, dan angket motivasi belajar matematika diklasifikasikan menjadi lima kategori pilihan dengan rentang skala penilaian yaitu skor 1 , skor 2 , skor 3, skor 4, dan skor 5. Data berdasarkan kualifikasi produk yang akan dinilai. Berdasarkan data yang telah dikelompokkan kemudian dilakukan pengkategorian seperti terdapat pada Tabel 1 yang diadaptasi dari Azwar (2002, p.163).

Tabel 1. Pedoman Konversi Aktual menjadi Skor Skala Lima

\begin{tabular}{cc}
\hline Interval skor & Nilai \\
\hline$X>\bar{x}_{i}+1,5 S B_{i}$ & $\mathrm{~A}$ \\
$\bar{x}_{i}+0,5 S B_{i}<X \leq \bar{x}_{i}+1,5 S B_{i}$ & $\mathrm{~B}$ \\
$\bar{x}_{i}-0,5 S B_{i}<X \leq \bar{x}_{i}+0,5 S B_{i}$ & $\mathrm{C}$ \\
$\bar{x}_{i}-1,5 S B_{i}<X \leq \bar{x}_{i}-0,5 S B_{i}$ & $\mathrm{D}$ \\
$X \leq \bar{x}_{i}-1,5 S B_{i}$ & $\mathrm{E}$ \\
\hline
\end{tabular}

Keterangan:

$\bar{x}_{i}=$ mean (rerata) skor ideal

$=\frac{1}{2}($ skor maksimal ideal + skor minimal ideal $)$

$S B_{i}=$ simpanan baku ideal

$=\frac{1}{6}($ skor maksimal ideal - skor minimal ideal $)$

$X=$ skor aktual 
Skor maksimal ideal $=$ Lbutir kriteria $\times$ skor tertinggi

Skor minimum ideal $=$ Sbutir kriteria $\times$ skor terendah

Sedangkan data kualitatif dari tes kemampuan berpikir kritis mempunyai skala dari 0 sampai 10. Selanjutnya data tersebut dikonversikan ke skala lima yang didaptasi oleh Azwar (2002, p.163) seperti pada Tabel 1.

Kevalidan dari perangkat yang dikembangkan diperoleh dari hasil penilaian ahli terhadap perangkat yang dikembangkan. Hasil penilaian mencapai kualitas valid jika masingmasing penilaian komponen perangkat memperoleh nilai minimal baik (B) dan memperoleh kesimpulan umum minimal layak digunakan dengan revisi. Nilai baik (B) dicapai jika masing-masing komponen perangkat pembelajaran memperoleh: skor validasi silabus lebih dari 146,67; skor validasi RPP lebih dari 226,67; skor validasi handout lebih dari 153,33; skor validasi LKS lebih dari 113,33; dan skor validasi tes ketercapaian kompetensi lebih dari $256,67$.

Kepraktisan diperoleh jika penilaian guru mendapatkan kategori nilai minimal baik (B); peserta didik yang memberikan penilaian minimal baik (B) sebanyak minimal $80 \%$ peserta didik; dan persentase keterlaksanaan pembelajaran minimal $80 \%$. Penilaian guru terhadap perangkat pembelajaran memperoleh nilai minimal baik (B) jika skor yang diberikan guru terhadap silabus, handout, dan tes ketercapaian kompetensi masing-masing lebih dari 16,67; skor RPP dan LKS masing-masing lebih dari 23,33 . Penilaian peserta didik terhadap handout dan LKS memperoleh nilai minimal baik jika skor yang diberikan lebih dari 50.

Keefektifan diperoleh jika hasil tes ketercapaian kompetensi yang mencapai KKM sebanyak minimal $80 \%$ peserta didik. Menurut Kemp, Morrison, \& Ross (1994, p.289) bahwa kualitas efektif dapat dicapai dengan memperhatikan peningkatan level penguasaan yang dicapai oleh peserta didik tiap tujuan pembelajaran. Berdasarkan penjelasan tersebut maka keefektifan ditinjau dari tes kemampuan berpikir kritis dalam penelitian ini yaitu jika banyak peserta didik yang mengalami peningkatan kategori lebih banyak dibandingkan dengan banyak peserta didik yang mengalami penurunan kategori dari pretest ke posttest. Kualitas efektif ditinjau dari motivasi belajar matematika diperoleh jika banyak peserta didik yang mengalami peningkatan motivasi belajar matematika lebih banyak dibandingkan dengan banyak peserta didik yang mengalami penurunan kategori motivasi belajar matematika sebelum dan sesudah pembelajaran.

\section{HASIL DAN PEMBAHASAN}

Hasil penelitian pengembangan ini berupa perangkat pembelajaran berbasis penemuan terbimbing untuk meningkatkan kemampuan berpikir kritis dan motivasi belajar matematika pada bangun ruang di SMP yang meliputi silabus, RPP, handout, LKS, dan tes ketercapaian kompetensi yang valid, praktis, dan efektif. Kompetensi yang digunakan pada perangkat pembelajaran meliputi bangun ruang sisi datar dan kompetensi bangun ruang sisi lengkung.

Silabus yang dikembangkan merupakan kajian kompetensi bangun ruang sisi datar kelas VIII dengan standar kompetensi 5 yaitu memahami sifat-sifat kubus, balok, prisma, limas, dan bagian-bagiannya, serta menentukan ukurannya; serta kompetensi bangun ruang sisi lengkung kelas IX dengan standar kompetensi 2 yaitu memahami sifat-sifat tabung, kerucut dan bola, serta menentukan ukurannya. Masing-masing standar kompetensi yang dikembangkan memuat tiga kompetensi dasar. Pengembangan silabus ini disesuaikan dengan silabus yang telah ada di sekolah.

Rencana Pelaksanaan Pembelajaran (RPP) yang dikembangkan merupakan penjabaran dari silabus. RPP yang dikembangkan beracuan pada Permendikbud Nomor 41 Tahun 2007 tentang Standar Proses. Indentitas mata pelajaran, standar proses, kompetensi dasar, indikator pelajaran, tujuan pembelajaran, materi ajar, alokasi waktu, metode pembelajaran, kegiatan pembelajaran, penilaian hasil belajar, dan sumber belajar. RPP yang dikembangkan menggambarkan prosedur pembelajaran berbasis penemuan terbimbing yang masing-masing terdiri atas tiga RPP pada kompetensi bangun ruang sisi datar dan kompetensi bangun ruang sisi lengkung.

Handout merupakan bahan tertulis yang disiapkan oleh guru untuk memperkaya pengetahuan peserta didik (Depdiknas, 2008, p.12). Handout yang dikembangkan berfungsi sebagai penunjang proses penemuan dalam LKS. Handout yang dikembangkan terdiri atas delapan handout pada kompetensi bangun ruang sisi datar dan dua handout pada bangun ruang sisi lengkung. 
Lembar Kegiatan Siswa (LKS) berisi kompetensi bangun ruang yang dituangkan dalam tahapan penemuan terbimbing. Dalam tahapan penemuan terbimbing meliputi identifikasi masalah, mengumpulkan informasi, menggunakan informasi yang digunakan dalam proses penemuan, dan evaluasi. Pertanyaanpertanyaan yang terdapat dalam LKS yang mengarahkan peserta didik dalam penemuan konsep yang terangkum dalam tahapan penemuan terbimbing dapat menunjang kemampuan berpikir kritis peserta didik. LKS yang dikembangkan terdiri atas delapan LKS pada kompetensi bangun ruang sisi datar, dan empat LKS pada kompetensi pada bangun ruang sisi lengkung.

LKS dan handout dilengkapi dengan gambar yang menunjang proses penemuan. Selain itu, LKS dan handout juga dilengkapi informasi tentang pentingnya kompetensi yang dipelajari. Tahap pembelajaran penemuan terbimbing juga tergambar dalam RPP yang dikembangkan.

Tes Ketercapaian kompetensi dirancang untuk mengetahui pencapaian kompetensi peserta didik yang dicapai. Tes ketercapaian kompetensi yang dikembangkan disusun secara sistematik pada bangun ruang sisi datar mengacu pada standar kompetensi yaitu memahami sifat-sifat kubus, balok, prisma, limas, dan bagian-bagiannya, serta menentukan ukurannya, sedangkan tes ketercapaian kompetensi pada bangun ruang sisi lengkung mengacu pada standar kompetensi yaitu memahami sifat-sifat tabung, kerucut dan bola, serta menentukan ukurannya. Tes ketercapaian kompetensi terdiri atas 20 soal pilihan ganda pada masing-masing standar kompetensi yang dikembangkan.

Penilaian kevalidan perangkat pembelajaran dilakukan oleh dua orang dosen pendidik- an matematika. Hasil validasi perangkat pembelajaran bangun ruang sisi datar dan bangun ruang sisi lengkung dapat dilihat dalam Tabel 2 dan Tabel 3.

Tabel 2. Skor Validasi Silabus, RPP, Handout, dan LKS Bangun Ruang Sisi Datar

\begin{tabular}{cccccc}
\hline \multirow{2}{*}{ Validator } & \multicolumn{5}{c}{ Skor perangkat yang divalidasi } \\
\cline { 2 - 6 } & Silabus & RPP & Handout & LKS & Tes \\
\hline 1 & 89 & 137 & 92 & 68 & 216 \\
2 & 82 & 126 & 85 & 62 & 218 \\
Skor Total & 171 & 263 & 177 & 130 & 434 \\
Nilai & B & B & B & B & A \\
Kategori & Baik & Baik & Baik & Baik & $\begin{array}{c}\text { Sangat } \\
\text { Baik }\end{array}$ \\
\hline
\end{tabular}

Tabel 3. Skor Validasi Silabus, RPP, Handout, dan LKS Bangun Ruang Sisi Lengkung

\begin{tabular}{cccccc}
\hline \multirow{2}{*}{ Validator } & \multicolumn{5}{c}{ Skor perangkat yang divalidasi } \\
\cline { 2 - 6 } & Silabus & RPP & Handout & LKS & Tes \\
\hline 1 & 90 & 138 & 92 & 69 & 220 \\
2 & 86 & 123 & 84 & 62 & 210 \\
Skor Total & 176 & 261 & 176 & 131 & 430 \\
Nilai & B & B & B & B & A \\
Kategori & Baik & Baik & Baik & Baik & $\begin{array}{c}\text { Sangat } \\
\text { Baik }\end{array}$ \\
\hline
\end{tabular}

Skor validasi dari perangkat yang dikembangkan memperoleh skor minimal baik dengan kesimpulan umum minimal layak digunakan dengan revisi sehingga memenuhi kualitas valid. Kepraktisan dari perangkat yang dikembangkan diperoleh dari penilaian guru terhadap perangkat yang dikembangkan, penilaian peserta didik terhadap handout dan LKS, serta hasil observasi keterlaksanaan pembelajaran. Skor penilaian dari guru dan peserta didik adalah data kuantitatif yang selanjutnya dikonversi ke skala pengkategorian yang diadaptasi dari Azwar (2002, p.163). Skor penilaian dari guru disajikan dalam Tabel 4.

Tabel 4. Skor penilaian perangkat oleh guru

\begin{tabular}{cccccc}
\hline \multicolumn{5}{c}{ Skor } \\
\hline Komponen & Silabus & RPP & Handout & LKS & Tes Ketercapaian Kompetensi \\
\hline \multicolumn{5}{c}{ Sekolah 1 } \\
\hline Skor & 23 & 32,38 & 23,38 & 33,38 & 25 \\
Nilai & A & A & A & A & A \\
Kategori & Sangat Baik & Sangat Baik & Sangat Baik & Sangat Baik & Sangat Baik \\
\multicolumn{7}{c}{} \\
\hline \multicolumn{7}{c}{ Sekolah 2 } \\
\hline Total skor & 23 & 31,75 & 21,88 & 30,75 & 23 \\
Nilai & A & A & A & A & A \\
Kategori & Sangat Baik & Sangat Baik & Sangat Baik & Sangat Baik & Sangat Baik \\
\hline
\end{tabular}


Hasil penilaian dari guru dari masingmasing sekolah memperoleh nilai minimal baik (B) untuk masing-masing komponen perangkat yang dikembangkan. Hal tersebut menunjukkan bahwa perangkat yang dikembangkan telah memenuhi kualitas praktis ditinjau dari penilaian guru. Skor penilaian peserta didik yang berupa data kuantitatif selanjutnya dikonversi ke skala pengkategorian yang diadaptasi dari Azwar (2002, p.163). Skor penilaian dari peserta didik disajikan dalam Tabel 5.

Tabel 5. Skor Penilaian Perangkat oleh Peserta Didik

\begin{tabular}{ccccc}
\hline & \multicolumn{2}{c}{ Sekolah 1 } & \multicolumn{2}{c}{ Sekolah 2 } \\
\cline { 2 - 5 } Nilai & $\begin{array}{c}\text { Banyak } \\
\text { Peserta } \\
\text { Didik }\end{array}$ & Persentase & $\begin{array}{c}\text { Banyak } \\
\text { Peserta } \\
\text { Didik }\end{array}$ & Persentase \\
\hline A & 16 & $49 \%$ & 2 & $6 \%$ \\
B & 11 & $33 \%$ & 26 & $74 \%$ \\
C & 5 & $15 \%$ & 7 & $20 \%$ \\
D & 1 & $3 \%$ & 0 & $0 \%$ \\
E & 0 & $0 \%$ & 0 & $0 \%$ \\
\hline
\end{tabular}

Peserta didik di sekolah 1 yang memberi penilaian mimimal baik (B) sebanyak 27 atau sebesar $82 \%$. Sedangkan peserta didik di sekolah 2 yang memberikan penilaian minimal baik (B) sebanyak 28 orang atau sebesar $80 \%$. Banyak peserta didik dari masing-masing sekolah tersebut memberikan penilaian minimal baik (B) lebih dari $80 \%$ sehingga perangkat pembelajaran mencapai kualitas praktis ditinjau dari penilaian peserta didik.

Data observasi keterlaksanaan pembelajaran diperoleh dari observasi keterlaksanaan pembelajaran di kelas yang dilakukan oleh guru pada setiap pertemuan dengan menggunakan perangkat pembelajaran yang dikembangkan. Observasi dilakukan oleh observer dengan menggunakan lembar observasi yang telah dibuat oleh peneliti. Data hasil observasi keterlaksanaan pembelajaran pada masing-masing sekolah selama delapan kali pertemuan disajikan dalam Tabel 6.

Kepraktisan pada perangkat pembelajaran ditinjau berdasarkan keterlaksanaan model pembelajaran diperoleh apabila persentase keterlaksanaan pembelajaran minimal $80 \%$. Berdasarkan tabel tersebut, dapat disimpulkan bahwa perangkat pembelajaran memenuhi kualitas praktis ditinjau dari keterlaksanaan model pembelajaran baik di sekolah 1 maupun di sekolah 2. Dengan demikian, dapat disimpulkan bahwa perangkat pembelajaran yang dikembangkan mencapai kualitas praktis ditinjau dari penilaian guru, penilaian peserta didik, dan observasi keterlaksanaan pembelajaran.

Tabel 6. Data Observasi Keterlaksanaan Pembelajaran

\begin{tabular}{lccc}
\hline No & $\begin{array}{c}\text { Pertemuan } \\
\text { ke- }\end{array}$ & \multicolumn{2}{c}{$\begin{array}{c}\text { Persentase Keterlaksanaan } \\
\text { Pembelajaran }(\%)\end{array}$} \\
\cline { 3 - 4 } & & Sekolah 1 & Sekolah 2 \\
\hline 1. & I & 92 & 92 \\
2. & II & 83 & 92 \\
3. & III & 92 & 92 \\
4. & IV & 83 & 92 \\
5. & V & 83 & 92 \\
6. & VI & 83 & 100 \\
7. & VII & 92 & 92 \\
8. & VIII & 92 & 92 \\
Rata-rata & & 88 & 93 \\
\hline
\end{tabular}

Kefektifan dari perangkat yang dikembangkan diperoleh dari hasil tes ketercapaian kompetensi, tes kemampuan berpikir kritis, dan angket motivasi belajar matematika. Tes ketercapaian kompetensi merupakan pencapaian ketuntasan belajar peserta didik secara individual dan persentase ketuntasan peserta didik secara klasikal yaitu sebanyak $80 \%$ dari banyak siswa dalam satu kelas telah memenuhi nilai kriteria ketuntasan minimal (KKM). Berdasarkan data hasil tes ketercapaian kompetensi diperoleh analisis seperti pada tabel 7 .

Tabel 7. Data Tes Ketercapaian Kompetensi

\begin{tabular}{llccc}
\hline No. Kelas & $\begin{array}{c}\text { Nilai } \\
\text { rata- } \\
\text { rata }\end{array}$ & $\begin{array}{c}\text { Bnyak } \\
\text { Peserta } \\
\text { Didik }\end{array}$ & $\begin{array}{c}\text { Persentase } \\
\text { Banyak Peserta } \\
\text { Didik yang } \\
\text { Nilainya } \geq 75\end{array}$ \\
\hline 1 & $8 \mathrm{~B}$ & 81,82 & 33 & $82 \%$ \\
2 & $8 \mathrm{~A}$ & 89,71 & 35 & $100 \%$ \\
\hline
\end{tabular}

Hasil analisis sekolah 1 (kelas 8B) menunjukkan bahwa ketuntasan klasikal mencapai $82 \%$ atau sebanyak 27 peserta didik, sedangkan ketuntasan klasikal sekolah 2 (kelas 8A) mencapai $100 \%$. Hal ini menunjukkan bahwa sekolah 1 dan sekolah 2 sudah memenuhi kualitas efektif ditinjau dari tes ketercapaian kompetensi.

Data kemampuan berpikir kritis dan motivasi belajar matematika diperoleh sebelum dan sesudah perlakuan pembelajaran. Data kuantitatif yang berupa skor tes kemampuan berpikir kritis dan angket motivasi belajar matematika dikonversi menjadi data kualitatif menjadi skala pengkategorian yang didaptasi dari Azwar (2002, p.163). Skor tes kemampuan berpikir kritis peserta didik sebelum dan sesudah pelaksanaan pembelajaran disajikan dalam Tabel 8 . 
Pythagoras, 11 (2), Desember 2016 - 215

Siti Nuriyatin, H. Hartono

Tabel 8. Data Tes Kemampuan Berpikir Kritis

\begin{tabular}{|c|c|c|c|c|c|}
\hline \multirow{3}{*}{ Kelas } & \multirow{3}{*}{ Kategori } & \multicolumn{4}{|c|}{ Pelaksanaan } \\
\hline & & \multicolumn{2}{|l|}{ Sebelum } & \multicolumn{2}{|l|}{ Sesudah } \\
\hline & & Banyak Peserta Didik & Persentase & Banyak Peserta Didik & Persentase \\
\hline \multirow{5}{*}{$8 B$} & Sangat Tinggi & 0 & $0 \%$ & 5 & $15 \%$ \\
\hline & Tinggi & 0 & $0 \%$ & 11 & $33 \%$ \\
\hline & Cukup Tinggi & 0 & $0 \%$ & 7 & $21 \%$ \\
\hline & Rendah & 10 & $30 \%$ & 6 & $18 \%$ \\
\hline & Sangat Rendah & 23 & $70 \%$ & 4 & $12 \%$ \\
\hline \multirow[t]{3}{*}{ Total } & & 33 & $100 \%$ & 33 & $100 \%$ \\
\hline & Sangat Tinggi & 0 & $0 \%$ & 15 & $45 \%$ \\
\hline & Tinggi & 1 & $3 \%$ & 12 & $36 \%$ \\
\hline \multirow[t]{3}{*}{$8 \mathrm{~A}$} & Cukup Tinggi & 8 & $23 \%$ & 4 & $12 \%$ \\
\hline & Rendah & 13 & $37 \%$ & 2 & $6 \%$ \\
\hline & Sangat Rendah & 13 & $37 \%$ & 0 & $0 \%$ \\
\hline Total & & 35 & $100 \%$ & 35 & $100 \%$ \\
\hline
\end{tabular}

Skor perubahan kategori kemampuan berpikir kritis sebelum dan sesudah pembelajaran ditunjukkan dalam Tabel 9.

Tabel 9. Data Perubahan Kategori Kemampuan

Berpikir Kritis Sebelum dan Sesudah Pelaksanaan Pembelajaran

\begin{tabular}{|c|c|c|c|c|}
\hline No. & Kelas & Keterangan & $\begin{array}{c}\text { Banyak } \\
\text { Peserta } \\
\text { Didik }\end{array}$ & Persentase \\
\hline \multirow{3}{*}{1.} & \multirow{3}{*}{$8 B$} & Menurun & 0 & $0 \%$ \\
\hline & & Tetap & 4 & $12 \%$ \\
\hline & & Meningkat & 29 & $88 \%$ \\
\hline \multirow{2}{*}{\multicolumn{2}{|c|}{ Total }} & Total & 33 & $100 \%$ \\
\hline & & Menurun & 0 & $0 \%$ \\
\hline \multirow[t]{3}{*}{2.} & \multirow[t]{2}{*}{$8 \mathrm{~A}$} & Tetap & 0 & $0 \%$ \\
\hline & & Meningkat & 35 & $100 \%$ \\
\hline & otal & Total & 35 & $100 \%$ \\
\hline
\end{tabular}

Hasil analisis sekolah 1 menunjukkan bahwa banyak peserta didik yang mengalami peningkatan lebih besar dibandingkan dengan banyak peserta didik yang mengalami penurunan. Banyak peserta didik yang mengalami peningkatan adalah 29 peserta didik atau sebesar $88 \%$. Sedangkan hasil tes kemampuan berpikir kritis sekolah 2 menunjukkan bahwa banyak peserta didik yang mengalami peningkatan adalah 35 peserta didik atau sebesar $100 \%$. Hal ini menunjukkan bahwa perangkat pembelajaran yang dikembangkan dapat meningkatkan kemampuan berpikir kritis pada 2 sekolah. Hasil peningkatan tersebut menunjukkan bahwa perangkat pembelajaran yang dikembangkan telah mampu meningkatkan kemampuan berpikir kritis peserta didik pada kompetensi bangun ruang sisi datar.

Data angket motivasi belajar matematika berupa data kuantitatif yang selanjutnya dikonversi menjadi data kualitatif menjadi skala pengkategorian yang didaptasi dari Azwar (2002, p.163). Data hasil angket motivasi belajar matematika sebelum dan sesudah pelaksanaan pembelajaran disajikan dalam Tabel 10.

Tabel 10. Data Motivasi Belajar Matematika

\begin{tabular}{clcc}
\hline \multirow{2}{*}{ Kelas } & \multirow{2}{*}{ Kategori } & \multicolumn{2}{c}{$\begin{array}{c}\text { Pelaksanaan } \\
\text { (Banyak Peserta Didik) }\end{array}$} \\
\cline { 3 - 4 } & & Sebelum & Sesudah \\
\hline \multirow{4}{*}{ 8B } & Sangat Tinggi & 7 & 6 \\
& Tinggi & 18 & 24 \\
& Cukup Tinggi & 8 & 2 \\
& Rendah & 0 & 1 \\
Total & Sangat Rendah & 0 & 0 \\
& & 33 & 33 \\
& Sangat Tinggi & 3 & 3 \\
8A & Tinggi & 24 & 26 \\
& Cukup Tinggi & 6 & 6 \\
& Rendah & 2 & 0 \\
\multirow{2}{*}{ Total } & Sangat Rendah & 0 & 0 \\
\hline
\end{tabular}

Skor perubahan kategori motivasi belajar matematika sebelum dan sesudah pembelajaran ditunjukkan dalam Tabel 11.

Tabel 11. Data Perubahan Kategori Motivasi Belajar Matematika Sebelum dan Sesudah Pelaksanaan Pembelajaran

\begin{tabular}{|c|c|c|c|c|}
\hline No. & Kelas & Keterangan & $\begin{array}{c}\text { Banyak } \\
\text { Peserta } \\
\text { Didik }\end{array}$ & Persentase \\
\hline \multirow{3}{*}{1.} & \multirow{3}{*}{$8 \mathrm{~B}$} & Menurun & 4 & $12 \%$ \\
\hline & & Tetap & 22 & $67 \%$ \\
\hline & & Meningkat & 7 & $21 \%$ \\
\hline \multirow{2}{*}{\multicolumn{2}{|c|}{ Total }} & Total & 33 & $100 \%$ \\
\hline & & Menurun & 5 & $14 \%$ \\
\hline \multirow[t]{3}{*}{2.} & \multirow[t]{2}{*}{$8 \mathrm{~A}$} & Tetap & 22 & $63 \%$ \\
\hline & & Meningkat & 8 & $23 \%$ \\
\hline & otal & Total & 35 & $100 \%$ \\
\hline
\end{tabular}


Peserta didik pada Sekolah 1 yang mengalami peningkatan motivasi belajar matematika sebanyak 7 orang atau $21 \%$, sedangkan peserta didik di Sekolah 2 yang mengalami peningkatan motivasi belajar matematika sebanyak 8 orang atau $23 \%$. Banyak peserta didik yang mengalami peningkatan kategori motivasi belajar matematika di masing-masing kelas tersebut lebih banyak dibandingkan dengan banyak peserta didik yang mengalami penurunan. Hal ini menunjukkan bahwa perangkat yang dikembangkan memenuhi kualitas efektif ditinjau dari angket motivasi belajar matematika di dua sekolah tersebut. Adapun data motivasi belajar matematika ditinjau dari tiap indikator yang disajikan dalam Tabel 12.

Tabel 12. Data Perubahan Kategori Motivasi

Belajar Matematika Sebelum dan Sesudah Pembelajaran

\begin{tabular}{clcccccc}
\hline \multirow{2}{*}{ Kelas } & Perubahan & \multicolumn{6}{c}{ Indikator } \\
\cline { 3 - 8 } & Kategori & $\mathbf{1}$ & $\mathbf{2}$ & $\mathbf{3}$ & $\mathbf{4}$ & $\mathbf{5}$ & $\mathbf{6}$ \\
\hline \multirow{3}{*}{$8 \mathrm{~B}$} & Menurun & 8 & 3 & 5 & 7 & 4 & 9 \\
& Tetap & 15 & 21 & 24 & 15 & 21 & 19 \\
& Meningkat & 10 & 9 & 4 & 11 & 8 & 5 \\
\multirow{3}{*}{$8 \mathrm{~A}$} & Menurun & 11 & 9 & 9 & 7 & 10 & 10 \\
& Tetap & 12 & 14 & 15 & 13 & 12 & 14 \\
& Meningkat & 12 & 12 & 11 & 15 & 13 & 11 \\
\hline
\end{tabular}

Perubahan kategori motivasi belajar matematika peserta didik di kelas 8B yang mengalami peningkatan paling besar yaitu pada indikator adanya dorongan dan kebutuhan dalam belajar. Pada indikator ini, kelas 8B juga mengalami penurunan paling rendah sebanyak tiga peserta didik. Hal ini dapat dipengaruhi oleh pemahaman peserta didik yang lebih tinggi di kelas tersebut terhadap pentingnya belajar bagi mereka. Perubahan kategori motivasi belajar matematika peserta didik di kelas 8A yang mengalami peningkatan paling tinggi yaitu pada indikator adanya penghargaan dalam belajar sebanyak 15 peserta didik. Penurunan kategori motivasi belajar matematika paling rendah juga terjadi pada indikator tersebut. Hal ini dikarenakan adanya faktor pemberian penghargaan yang baik yang diberikan selama proses pembelajaran berlangsung. Dengan demikian, dapat disimpulkan bahwa perangkat pembelajaran yang dikembangkan memenuhi kualitas efektif ditinjau dari tes ketercapaian kompetensi, tes kemampuan berpikir kritis, dan motivasi belajar matematika.

\section{SIMPULAN DAN SARAN}

\section{Simpulan}

Pengembangan perangkat pembelajaran berbasis penemuan terbimbing untuk meningkatkan kemampuan berpikir kritis dan motivasi belajar matematika pada bangun ruang di SMP ini melalui tahap pengembangan $4 \mathrm{D}$ yang meliputi define, design, develope, dan disseminate. Perangkat pembelajaran bangun ruang sisi datar kelas VIII yang dikembangkan terdiri atas silabus, 3 RPP, 8 handout, 8 LKS, dan 1 perangkat tes ketercapaian kompetensi. Sedangkan perangkat pembelajaran bangun ruang sisi lengkung kelas IX meliputi silabus, 3 RPP, 2 handout, 4 LKS, dan 1 perangkat tes ketercapaian kompetensi. Produk pengembangan memuat tahapan penemuan terbimbing yaitu merumuskan masalah; mengumpulkan informasi; menggunakan informasi yang diperoleh; dan mengevaluasi. Tahapan penemuan terbimbing ini terdapat pada produk RPP dan LKS yang dikembangkan. Silabus yang dikembangkan berfungsi sebagai dasar pengembangan dari perangkat yang lainnya, sedangkan handout yang dikembangkan berfungsi sebagai penunjang dalam penggunaan LKS. Tes ketercapaian kompetensi yang dikembangkan berfungsi sebagai alat ukur dari penguasaan kompetensi peserta didik setelah menggunakan perangkat pembelajaran yang dikembangkan.

Kualitas perangkat pembelajaran berbasis penemuan terbimbing yang dikembangkan pada kompetensi bangun ruang sisi lengkung memenuhi kualitas valid, Sedangkan perangkat pembelajaran yang dikembangkan pada kompetensi bangun ruang sisi datar mempunyai kualitas valid, praktis, dan efektif.

\section{Saran}

Produk perangkat pembelajaran yang dihasilkan dapat digunakan sebagai referensi guru dalam menyusun perangkat pembelajaran matematika yang menunjang kemampuan berpikir kritis dan motivasi belajar matematika. Penggunaan produk perangkat pembelajaran berbasis penemuan terbimbing ini dapat didampingi dengan berbagai sumber belajar yang lainnya selain handout yang dikembangkan untuk memperoleh hasil yang maksimal.

\section{DAFTAR PUSTAKA}

Anggraeni, N., Ristiati, N., \& Widiyanti, N. (2013). Implementasi strategi pembelajaran inkuiri terhadap 
kemampuan berpikir kritis dan pemahaman konsep IPA siswa SMP. $e$ Journal Program Pascasarjana Universitas Pendidikan Ganesha Program Studi IPA, 3(2), 1-11.

Arends, R., \& Kilcher, A. (2010). Teaching for student learning, becoming an accomplished teacher. New York, NY: Routledge.

Azwar, S. (2002). Sikap manusia teori dan pengukurannya. Yogyakarta: Pustaka Pelajar.

Bell, F. H. (1981). Teaching and learning mathematics (In secondary school). Dubuque, IO: Wm. C. Brown Company.

Bruner, J. S. (2006). In search of pedagogy: Volume 1. New York, NY: Routledge.

Carin, A. A., \& Sund, R. B. (1989). Teaching science through discoverry. Columbus, $\mathrm{OH}$ : Merrill Publising Company.

Cottrell, S. (2005). Critical thinking skills, developing effective analysis and argument. New York, NY: Palgrave Macmillan.

Depdiknas. (2002). Pendekatan kontekstual. Jakarta: Direktorat Pendidikan.

Depdiknas. (2003). Penjelasan Undang-Undang Republik Indonesia Nomor 20 Tahun 2003, tentang Sistem Pendidikan Nasional.

Depdiknas (2006). Peraturan Menteri Pendidikan Nasional Republik Indonesia Nomor 23 Tahun 2006, tentang Standar Kompetensi Lulusan Untuk Satuan Pendidikan Dasar dan Menengah.

Depdiknas. (2007). Peraturan Menteri Pendidikan Nasional Republik Indonesia Nomor 41 Tahun 2007, tentang Standar Proses Untuk Satuan Pendidikan Dasar dan Menengah

Depdiknas. (2008). Panduan pengembangan bahan ajar. Jakarta: Direktorat Jenderal Manajemen Pendidikan Dasar dan Menengah.

Elliott, S., et. al. (2000). Educational psychology: effective teaching, effective learning $\left(3^{\text {th }} e d\right)$. New York, NY: McGraw-Hill.
Ennis, R. H. (2011). The nature of critical thinking: an outline of critical thinking dispositions and abilities. Chicago, IL: University of Illinois.

Facione, P. (2011). Critical thinking: what it is and why it counts. Hermosa Beach, CA: The California Academic Press.

Fisher, A. (2009). Critical thinking: An introduction. Cambridge, UK: Cambridge University.

French, D. (2004). Teaching and learning geometry: issues and methods in mathematical education. New York, NY: Continum.

Gredler, M. (2011). Learning and instruction $\left(6^{\text {th }}\right.$ ed.). New York, NY: McGraw-Hill.

Imawan, O. R. (2015). Perbandingan antara keefektifan model guided discovery learning dan project-based learning pada matakuliah geometri. PYTHAGORAS: Jurnal Pendidikan Matematika, 10(2), 179-188. doi:http://dx.doi.org/10.21831/pg.v10i2.9 156.

Kemp, J., Morrison, G., \& Ross, S. (1994). Designing effective instruction. New York, NY: Macmillan College Publishing Company.

Kuhlthau, C. et al. (2007). Guided inquiry, learning in the $21^{\text {st }}$ century. London, $\mathrm{UK}$ : Libraries Unlimited.

Kuhlthau, C. (2010). Guided inquiry: school libraries in the $21^{\text {st }}$ century. The International Association of School Librarianship, 16(1), 17-28.

Lai, E. R. (2011). Critical thinking: a literature review.

http://images.pearsonassessments.com/im ages/tmrs/CriticalThinkingReviewFINAL .pdf.

Lunenburg, F. (2012). Teachers' use of theoretical frames for instructional planning: critical thinking, cognitive, and constructivist theories. International Journal Of Scholarly Academic Intellectual Diversity, 14(1), 1-9.

Masduki, dkk. (2013, November). Level kognitif soal-soal buku pelajaran matematika SMP. Makalah dipresentasikan dalam Seminar Nasional Matematika dan 
Pendidikan Matematika "Penguatan Peran Matematika dan Pendidikan Matematika untuk Indonesia yang Lebih Baik", di Universitas Negeri Yogyakarta.

Moore, K. D. (2009). Effective instructional strategies: From teory to practice. London, UK: SAGE Publication.

Moore, B. \& Stanley, T. (2010). Critical thinking and formative assessments: increasing the rigor in your classroom. New York, NY: Eye on Education.

Nieveen, N., et.al. (1999). Design approaches and tools in educationand. Netherland: Kluwer Academic Publishers.

Rosnawati, R. (2013, Mei). Kemampuan penalaran matematika siswa SMP Indonesia pada TIMSS 2011. Makalah disajikan dalam Seminar Nasional Penelitian, Pendidikan dan Penerapan MIPA, di Universitas Negeri Yogyakarta.
Thiagarajan, S., Semmel, D. S. Dan Semmel, M. I. (1974). Instructional development for tarining teachers of exceptional children. Minnepolis, MA: University of Minnesota.

Throwbridge, L. W., \& Bybee, R. W. (1986). Becoming secondary school science teacher $\left(4^{\text {th }} e d\right)$. Columbus, $\mathrm{OH}$ : Merrill Publishing Company.

Uno, H. (2006). Teori motivasi dan pengukurannya. Jakarta: Bumi Aksara.

Yuliyanto, Y., \& Jailani, J. (2014). Pengembangan perangkat pembelajaran geometri SMP menggunakan metode penemuan terbimbing pada kelas VIII semester II. Jurnal Riset Pendidikan Matematika, $\quad$ l(1), 127-138. doi:http://dx.doi.org/10.21831/jrpm.v1i1 . 2670 